\title{
Identification and Evaluation of Nutrient Compositions of Two Wild Edible Mushrooms in Oduoha-Emohua Forest, Rivers State
}

\author{
CHUKUNDA F. A. \& NNADI P. C.
}

Department of Forestry and Environment, Faculty of Agriculture, Rivers State University, Port Harcourt, Nigeria.

\section{ARTICLE INFO}

Article No.: 050918068

Type: Research

DOI: 10.15580/GJAS.2018.7.050918068

Submitted: 09/05/2018

Accepted: 04/06/2018

Published: 27/07/2018

${ }^{*}$ Corresponding Author

Chukunda, F. A.

E-mail: onyifrank2002@

yahoo.com

Phone: 08037501179

Keywords: Proximate compositions wild edible mushrooms, nutrient values, macro-morphological characteristics, Oduoha-Emohua forest.

\section{ABSTRACT}

The objective of the work was to identify and evaluate the proximate compositions of two wild edible mushrooms collected from OduohaEmohua forest. Two wild edible mushrooms were collected and identified using the habitat, macro-morphological characteristics such as colour, cap length, stipe length and fresh fruit body weight. The mushrooms identified include; Pleurotus citrinopileatus (Hilber, 0 ) Singer and Pleurotus tuber-regium (Fr.) Singer. The Experiment was laid out in a Completely Randomized Design (CRD) with four replicates. Results of proximate compositions of the two wild edible mushrooms collected, indicated that there was significant difference $(P \leq 0.05)$ in crude protein $(5.99 \pm 0.72-11.76 \pm 0.58)$, total carbohydrate $(31.24 \pm 270-36.42 \pm 2.83)$, moisture content $(4.56 \pm 0.91-10.86 \pm 0.6)$, crude fibre $(42.62 \pm 3.24-45.62 \pm 3.46)$, and total lipids $(3.18 \pm 0.38-$ $3.46 \pm 0.42)$ in the two Pleurotus species. Percentage crude protein of Pleurotus citrinopileatus was significantly higher $(11.76 \% \pm 0.72)$. However, Pleurotus tuber-regium had the highest nutrient values in total carbohydrate, moisture content, total lipids and total ash $(3.45 \pm 0.74-$ $4.65 \pm 0.43)$. Data collected were subjected to analysis of variance (ANOVA) and the mean separation was done using Duncan Multiple Range Test (DMRT) at the probability of $5 \%$ and mean of standard deviation. It is recommended therefore, that the production and consumption of these wild mushrooms identified especially Pleurotus citrinopileatus can generate income as well as improve the nutrient values when consumed regularly as food item. 


\section{INTRODUCTION}

Edible mushrooms are the fleshy and edible fruit bodies of several species of macrofungi (fungi which bear fruiting structures that are large enough to be seen with the naked eye). They can appear either below ground (hypogeous) or above ground (epigeous) where they may be picked by hand (Chang et al., 1989).

Edibility may be defined by criteria that include absence of poisonous effects on humans and desirable taste and aroma (Arora; 1986; Mattila et al., 2000). Edible mushrooms are consumed for their nutritional value and they are occasionally consumed for their supposed medicinal value. Mushrooms consumed by those practicing folk medicine are known as medicinal mushrooms (Chang et al., 1989). While, hallucinogenic mushrooms (e.g. psilocybin mushrooms) are occasionally consumed for recreational or religious purposes. They can produce severe nausea and disorientation, and are therefore not commonly considered edible mushrooms (Boa, 2004).

Edible mushrooms include many fungal species that are either harvested wild or cultivated. Easily cultivatable and common wild mushrooms are often available in markets, and those that are more difficult to obtain such as the prized truffle and matsutake may be collected on a smaller scale by private gatherers. Some preparations may render certain poisonous mushrooms fit for consumption (Boa, 2004).

Before assuming that any wild mushroom is edible, it should be identified. There should be accurate determination and proper identification of a species is the only safe way to ensure edibility and the only safeguard against possible accident. Some mushrooms that are edible for most people can cause allergic reactions in some individuals and old or improperly stored specimens can cause food poisoning. Great care should therefore be taken when eating any fungus for the first time and only small quantities should be consumed in case of individual allergies (Jordan, 2016).

Deadly poisonous mushrooms that are frequently confused with edible mushrooms and responsible for many fatal poisonings include several species of the Amanita genus, in particular, Amanita phalloides, the death cap. It is therefore better to eat only a few, easily recognizable species than to experiment indiscriminately. Moreover, even species of mushrooms that normally are edible, may be dangerous, as mushrooms growing in polluted locations can accumulate pollutants such as heavy metals (Kalac and Svoboda, 2000).

Mushrooms have been a food supplement in various cultures and they are cultivated and eaten for their edibility and delicacy. They fall between the best vegetables and animal protein source. Mushrooms are considered as source of proteins, vitamins, fats, carbohydrates, amino acids and minerals (Jiskani, 2001).
All essential amino acids are present as well as water soluble vitamins and all the essential minerals (Buigut, 2002). Mushroom are good sources of vitamins like riboflavin, biotin and thiamine (Chang and Buswell, 1996). Ogundana and Fagade (1981) indicated that mushroom is about $16.5 \%$ dry matter out of which $7.4 \%$ is crude fiber, $14.6 \%$ is crude protein and $4.48 \%$ is fat and oil. Protein contents vary between 4 to $9 \%$ in Auricularia sp. and between 24 to $44 \%$ in Agaricus species.

The protein value of mushrooms is twice as that of asparagus and potatoes, four times as that of tomatoes and carrots, and six times as that of oranges (Jiskani, 2001). Their energy value also varies according to species, which is about equal to that of an apple. Pleurotus tuber-regium is a common species in Southern part of Nigeria and it is useful in some combinations to cure headache, stomach ailments, colds and fever (Oso, 1977) asthma, smallpox and high blood pressure (Fasidi and Olorunmaiye, 1994; Oso, 1977), while Lentinus tuber-regium and $L$. tigrinus are used for treating dysentery and blood cleansing respectively.

Auricularia species have been traditionally used for treating hemorrhoids and various stomach ailments (Chang and Buswell, 1996). Chanterelles, Boletus edulis and Lactarius spp. are used for killing flies, while the puffballs are used for healing wounds (Harkonen, 1998; Delena, 1999). They are also recommended to diabetic and anemic persons, owing to their low carbohydrate and high folic acid content. Some mushrooms are reputed to possess anti-allergic, anticholesterol, antitumor and anti-cancer (Jiskani, 2001).

Identification and cultivation of wild edible mushrooms are important ecological concern as there have been concerns of depletion of larger fungi due to deforestation activities in our environment. Pleurotus species have been proven to be good wild edible mushrooms in Nigeria as it's added to the diet with ever increasing population. Also, Pleurotus spp are found to grow naturally in the forest, grassland and damp logs in Nigeria during the early and late raining seasons.

This research is aimed at identifying and evaluating the proximate compositions of two wild edible mushrooms obtained in Oduoha-Emohua Forest.

The specific objective of this research were to:

1. identify of the two wild edible mushrooms collected from Oduoha-Emohua Forest.

2. determine proximate compositions of the two wild edible mushrooms collected.

\section{MATERIALS AND METHODS}

\section{Study Area}

The field experiment was conducted at Oduoha-Emohua secondary forest situated at Latitude $04.75^{\circ} \mathrm{S}$, and $7.20^{\circ} \mathrm{N}$ and Longitude $5.5^{\circ} \mathrm{W}$ and $90.30^{\circ} \mathrm{E}$ in the 
rainforest zone of Rivers State. The study area lies in the zone of humid tropical climate which has two seasons, the wet season extends from March to October and dry season, extends from November to February. The mean annual temperature ranges from $21^{\circ} \mathrm{C}$ and $29^{\circ} \mathrm{C}$ (Chukunda et al., 2008).

\section{Collection and Identification of Wild Edible Mushrooms}

The sporocarps of matured mushroom species were randomly collected from their natural habitat using scapel. Collection was done between May and June 2017. Mushroom samples collected were Pleurotus citrinopileatus and Pleurotus tuber-regium. Identification of the samples of collected mushrooms was done macroscopically. Macro-morphological identification was based on habitat, colour, cap length, stipe length and fresh fruit body weights (Wasser 2007, Ukoima et al., 2009a; Chukunda et al., 2017). The identification of the species was done according to systematic criteria obtained from macroscopic examination (Wasser and Weis 1999; Wasser, 2007).

The photographs of the specimens were taken and the mushrooms were later taken to Mycology/Pathology Laboratory in the Department of Forestry and Environment, Rivers State University Nkpolu-Oroworukwo, Port Harcourt were it was oven dried at $60^{\circ} \mathrm{C}$ and preserved in the shelf for further analysis.

\section{Determination of Morphological Parameters of Two Wild Edible Mushrooms}

Cap length: This was determined by placing a transparent ruler across the center of the pileus of each harvested mushroom fruit body and reading off the diameter. (Ukoima et al., 2009a; Ukoima et al., 2009b; Ukoima et al., 2009c;)

Stipe length: This was determined by placing transparent ruler along the length of each fruit body stipe (Chukunda et al., 2017)

Fresh fruit body weights: This was determined by weighing each fresh fruit body immediately after harvest using a portable digital balance (Chukunda et al., 2017).

\section{Proximate Analysis of Mushroom}

\section{Protein content}

A half gram $(0.5 \mathrm{~g})$ each of the powdered Pleurotus citrinopileatus and Pleurotus tuber-regium mushroom samples were extracted with $2 \%$ Sodium chloride in a water- bath at $60^{\circ} \mathrm{C}$ for one hour. The extract was filtered out and 3\% copper acetate monohydrate was added to the filtrate to precipitate protein. The precipitated protein was then centrifuged out and dissolves in $50 \mathrm{~cm}^{3}$ of $0.01 \mathrm{M} \mathrm{NaOH}$. The quantity of protein in the alkaline solution was then determined using the Folin-phenol method (Kadiri and Fasidi, 1990). The following formula was used to convert nitrogen into protein. Protein $\%=$ $\mathrm{N} \% \times 4.38$ for mushrooms, which took into account the excluding non-protein $\mathrm{N}$ coming from the chitin of the cell wall of fungi (Miles and Chang, 1997).

\section{Total carbohydrate}

One gram of each of Pleurotus citrinopileatus and Pleurotus tuber-regium were digested using $13 \mathrm{ml}$ of $52 \%$ Perchloric acid diluted with water in the ratio of 270:100ml. One $\mathrm{ml}$ of the digest was pipetted into a test tube and $5 \mathrm{ml}$ of freshly prepared anthrone reagent was added, mixed and allowed to stand in a boiling water bath (Technotest 13539, Italy) for exactly 12 minutes.

The test tubes and its content was then removed and cooled to room temperature. The absorbances of the sample mixture and standard was read at $630 \mathrm{~nm}$ against the reagent blanks using a uv/visible spectrophotometer 754, and the total available carbohydrate content of the samples was calculated using the method of Osborne and Voogt (1978)

Total carbohydrate $(\%$ glucose $)=\frac{25 \times b}{a \times w}$

Where; $\mathrm{W}=$ weight $(\mathrm{g})$ of Pleurotus citrinopileatus and Pleurotus tuber-regium fruit bodies, a = absorbance of dilute standard, $\mathrm{b}=$ absorbance of diluted sample mushroom

\section{Moisture content}

The fresh fruit body weight of Pleurotus citrinopileatus and Pleurotus tuber-regium was weighed using a chemical balance. These samples were then oven dried separately at $8^{\circ} \mathrm{C}$ for 48 hours. The loss in weight obtained after drying was regarded as the moisture content (Manzi et al., 1990).

\section{Determination of crude fibre}

Half gram of samples of Pleurotus citrinopileatus and Pleurotus tuber-regium mushrooms were extracted for three hours with petroleum ether using a Soxhlet apparatus. The fat free material was placed in a $200 \mathrm{ml}$ beaker and $50 \mathrm{ml}$ of $1.25 \% \mathrm{w} / \mathrm{v}$ Sulphuric acid was added and covered with a watch glass. The content of the beaker was heated gently on a hot plate (Gehardt) for 30 minutes.

After acid hydrolysis, the content of the beaker was filtered under vacuum through a Buchner funnel fitted with filter paper and washed with boiling water until the washing was no longer acidic to litmus. The residue was washed into the original flask using a wash bottle containing $1.25 \%$ Sodium hydroxide. This was boiled for 30 minutes covered with a watch glass. The resulting insoluble material was transferred to a dried weighed ashless filter paper (What man No. 41) and washed 
thoroughly first with hot water and then with $15 \mathrm{ml}$ of ethanol (95\%) by volume. The filter paper and content was incinerated to ash at $50^{\circ} \mathrm{C}$ in a muffle furnace for $1 \mathrm{hr}$. The ash was allowed to cool and then weighed using the method of AOAC (2012). The weight of the ash was subtracted from the increase of weight on the paper due to the insoluble material and the difference reported as fibre.

Crude fibre $(\%)=\frac{\text { weight of fibre }}{\text { weight of sample }} \times 100$

\section{Lipids}

Two grams (2.0g) each of powder samples were extracted using petroleum ether in a soxhlet extractor for 4 hours. The extracts were evaporated to dryness in a weighed flask using a vacuum evaporator. The weighed flasks were dried in the oven at $80^{\circ} \mathrm{C}$ for 2 hours and allowed to cool and reweighed. The difference between the initial and final weights were regarded as the lipid content (Parent and Thoen, 1977).

\section{Ash content}

Three grams $(3.0 \mathrm{~g})$ each of powder mushroom samples of Pleurotus citrinopileatus and Pleurotus tuber-regium was ashed in a Gallenkamp furnace in previously ignited and cooled crucible of known weighted at $550^{\circ} \mathrm{C}$ for 6 hours. Fairly cooled crucibles were put in desiccators and weighted (Manzi et al., 1999).

\section{Experimental Design and Data Analysis}

The experiment was conducted in a completely randomized design (CRD), the treatment replicated four times. Data were statistically analyzed using the method of Steel and Torrie (1980), significant differences were declared using Duncan Multiple Range Test (DMRT) at a probability of $5 \%$.

\section{RESULTS}

\section{Macro-morphological Characteristics of Two Wild Edible Mushrooms}

The results on the macro-morphological characteristics of two wild edible mushrooms collected from OduohaEmohua forest are shown in Table 1 and Plate 1. The results revealed that Pleurotus citrinopileatus (Hilber, O) Singer and Pleurotus tuber-regium (Fr.) Singer were found within the period of collection (May/June, 2017). Pleurotus tuber-regium was found in the damp forest floor soil more than $P$. citrinopileatus. $P$. tuber-regium had the highest cap length $(3.35 \mathrm{~cm} \pm 1.07)$ while cap length of $P$. citrinopileatus was $(0.92 \mathrm{~cm} \pm 0.94)$, Stipe length of $P$. citrinopileatus was $(1.83 \mathrm{~cm} \pm 0.94), P$. tuberregium $(1.35 \mathrm{~cm} \pm 1.07)$ and the fresh fruit body weight of
$P$. tuber-regium was the highest $(8.55 \mathrm{~g} / \mathrm{kg} \pm 0.32)$ while $P$. citrinopileatus was $(5.96 \mathrm{~g} / \mathrm{kg} \pm 0.34)$.

\section{Proximate Composition of Two Wild Edible Mushrooms}

The results on the proximate compositions of two wild edible mushrooms; Pleurotus citrinopileatus and Pleurotus tuber-regium (Table 2). The results indicated that there was significant difference $(P \leq 0.05)$ in crude protein, total carbohydrate, moisture content, crude fibre, and total lipids in the two Pleurotus species. Percentage crude protein of Pleurotus citrinopileatus was significantly higher $(11.76 \% \pm 0.72)$. However, Pleurotus tuber-regium had the highest nutrient values in total carbohydrate, moisture content, total lipids and total ash.

\section{DISCUSSION}

\section{Macro-morphological Characteristics of Two Wild Edible Mushrooms}

In this study, two wild edible mushrooms were collected and identified using macro-morphological characteristics and these include; $P$. citrinopileatus and $P$. tuber-regium. The occurrence of these mushroom species has been reported by several researchers (Oei, 2003; Ellioth, 1991).

The results in Table 1 showed that wild mushrooms collected from Oduoha-Emohua naturally grew on dead woods and damped soils. These results are not surprising because the vegetation is a typical tropical rainforest, which supported their growth (Zoheri, 1972; Fasidi and Olorunmaye 1994; Alofe, et al., 1996, Jonathan and Fasidi, 2003). The mycophagy or acceptance and consumption of mushrooms vary from one location to another in Nigeria (Adejumo et al., 2015).

The consumption of wild edible mushrooms is dependent on their availability to augment for family income (Osemwegie et al., 2010). This report agreed with the findings of Odebode (2005) that mushrooms are used as food and medicine.

\section{Proximate Compositions of two wild edible mushrooms}

The results of proximate composition (Table 2) analysis of the wild mushrooms collected from Oduoha-Emohua forest revealed that the two wild edible mushrooms are significantly $(P \leq 0.05)$ rich in carbohydrate, moisture, crude proteins, lipids and total ash. It is known that high proximate composition of mushrooms is usually related to the pileus rather than stipe (Aletor and Aladetimi, 1995). Akindahunsi and Oyetayo (2006) who reported that Pleurotus tuber regium was rich in protein, lipids, ash and total carbohydrate.

The wild mushrooms collected were very important food item especially the Pleurotus tuber regium which were significant in proteins, high fibre content and low lipid which indicated that they are good 
mushrooms. In this study, the high fibre content observed among the three mushrooms agreed with the results obtained by Obodai (1992). The relative high percentage of carbohydrates in the two mushroom samples collected proved that they are nutritious and good for human consumption. This is in agreement with the report obtained by Marlow (2001). On the contrary the high moisture content of the mushrooms obtained may be an indication that most fresh mushrooms cannot be kept for a longer time. This may be due to high water content which favored microbial growth (Aletor, 1995). The study on the myco-proteins of the wild mushroom collected revealed that protein contents of mushrooms vary according to the genetic constitution and differences in growing medium (Samme et al., 2003; Adejumo and Awosanya, 2005). The present study agreed with the reports of Fasidi and Kadiri (1990) and Ola and Obah (2001) that some mushrooms, V. volvacea and $T$. robusta contain higher protein content. Similarly, Crisan and Sands (1978) and Chang and Miles (1989) reported that mushrooms had the highest amount of crude proteins compare to vegetables and cereals. This agreed with the present findings.

Table 1: Macro-Morphological Characteristics of Two Wild Edible Mushrooms Collected From Oduoha-Emohua Forest.

\begin{tabular}{|c|c|c|c|c|c|}
\hline \multirow[t]{2}{*}{ Mushroom species } & \multirow[b]{2}{*}{ Habitat } & \multicolumn{4}{|c|}{ Morphological descriptions } \\
\hline & & Colour & $\begin{array}{l}\text { Cap length } \\
\text { (cm) }\end{array}$ & $\begin{array}{l}\text { Stipe length } \\
\text { (cm) }\end{array}$ & $\begin{array}{l}\text { Fresh fruit } \\
\text { body weight } \\
(\mathrm{g} / \mathrm{kg})\end{array}$ \\
\hline $\begin{array}{l}\text { Pleurotus } \\
\text { citrinopileatus }\end{array}$ & $\begin{array}{l}\text { Damped } \\
\text { soil }\end{array}$ & Golden/yellow & $0.92 \pm 0.94^{b}$ & $1.83 \pm 0.94^{a}$ & $\begin{array}{l}5.96 \\
\pm 0.34^{\mathrm{b}}\end{array}$ \\
\hline $\begin{array}{l}\text { Pleurotus } \\
\text { tuber-regium }\end{array}$ & $\begin{array}{l}\text { Damped } \\
\text { soil }\end{array}$ & Brown & $3 . .35 \pm 1.07^{a}$ & $1.35 \pm 1.07^{b}$ & $8.55 \pm 0.32^{a}$ \\
\hline
\end{tabular}

Means followed by the sane alphabets within each column are not significantly different by DMRT $(P \leq 0.05)$, Means \pm Standard deviation $(n=4)$.

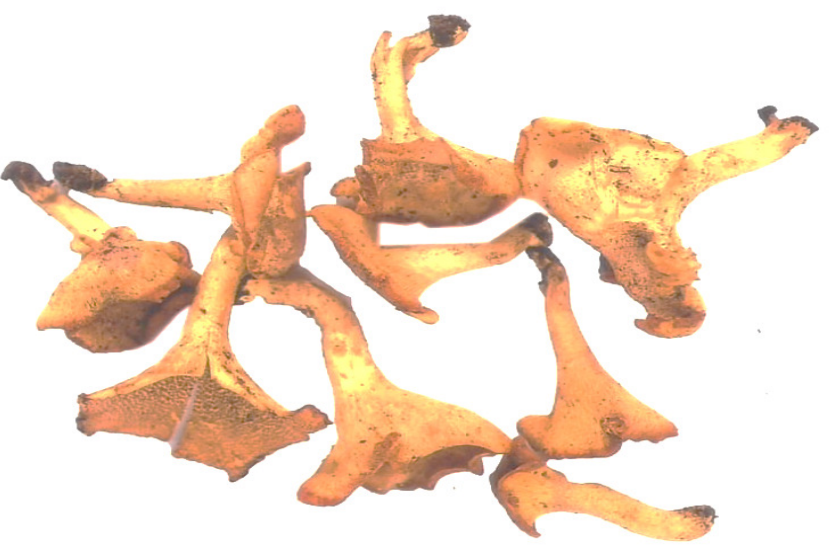

Pleurotus citrinopileatus

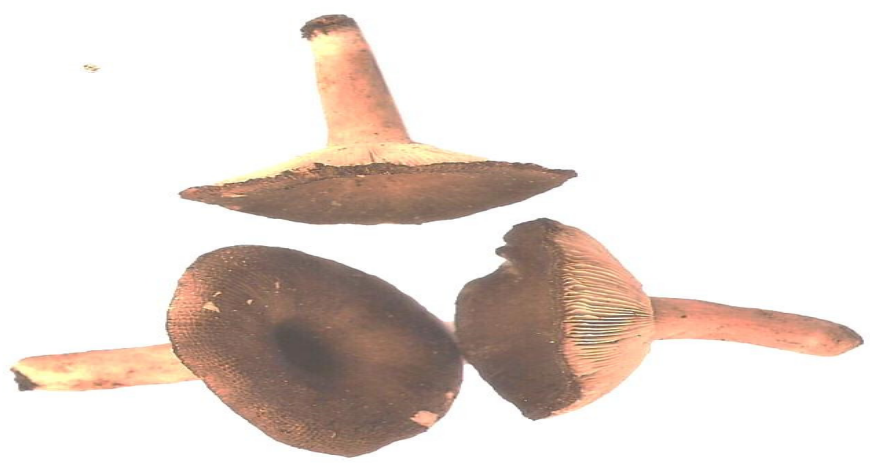

Pleurotus tuber-regium

Plate 1: Samples of mushrooms collected from Oduoha-Emohua Forest

Table 2: Proximate Compositions of Two Wild Edible Mushrooms Collected From Oduoha-Emohua Forest $(\mathbf{m g} / \mathbf{1 0 0 g})$

\begin{tabular}{|c|c|c|c|c|c|c|}
\hline $\begin{array}{l}\text { Mushroom } \\
\text { Samples }\end{array}$ & $\begin{array}{c}\text { Crude } \\
\text { protein } \\
(\%)\end{array}$ & $\begin{array}{l}\text { Total } \\
\text { carbohydra } \\
\text { te }(\%)\end{array}$ & $\begin{array}{c}\text { Moisture } \\
\text { content } \\
(\%)\end{array}$ & $\begin{array}{l}\text { Crude } \\
\text { fibre } \\
(\%)\end{array}$ & $\begin{array}{c}\text { Total } \\
\text { Lipids } \\
(\%)\end{array}$ & $\begin{array}{l}\text { Total } \\
\text { Ash } \\
(\%)\end{array}$ \\
\hline $\begin{array}{l}\text { Pleurotus } \\
\text { citrinopileatus }\end{array}$ & $\begin{array}{l}11.76 \pm \\
0.58^{a}\end{array}$ & $\begin{array}{l}31.24 \pm \\
2.70^{\mathrm{b}}\end{array}$ & $\begin{array}{l}4.56 \pm 0.9 \\
1^{b}\end{array}$ & $\begin{array}{l}42.62 \pm \\
3.24^{b}\end{array}$ & $3.18 \pm 0.38^{b}$ & $3.45 \pm 0.74^{b}$ \\
\hline $\begin{array}{l}\text { Pleurotus tuber- } \\
\text { regium }\end{array}$ & $\begin{array}{l}5.99 \pm 0.72 \\
b\end{array}$ & $\begin{array}{l}36.42 \pm \\
2.83^{a}\end{array}$ & $\begin{array}{l}10.86 \pm 0 \\
6^{a}\end{array}$ & $\begin{array}{l}45.62 \pm \\
3.46^{a}\end{array}$ & $3.46 \pm 0.42^{\mathrm{a}}$ & $4.65 \pm 0.43^{a}$ \\
\hline
\end{tabular}

Means followed by the same superscript letters within each column are not significantly different by DMRT $(p \leq 0.05)$, Mean \pm standard deviation $(n=4)$. 


\section{CONCLUSION AND RECOMMENDATIONS}

In developing country like Nigeria the use of wild edible mushrooms in the diet will help to reduce cost of supplementary nutrition of most people especially now that the cost of fish and meat is high. However, this study was able to identify two wild edible mushrooms; $P$. citrinopileatus and $P$. tuber-regium, which was found edible among the inhabitants of Oduoha-Emohua. Results from proximate analysis showed that nutrient assed were rich for human consumption and as a sources of prebiotics in the diet of man.

In conclusion the knowledge of mushroom identification through morphological characteristics will act as a guide and means of differentiating poisonous mushrooms from the edible ones especially now that the demand for mushrooms are on the increase for food and medicine.

\section{Recommendations}

1. $\quad P$. citrinopileatus and $P$. tuber-regium are recommended to be used as natural antibiotic against infection thereby reducing the cost of procuring synthetic antibiotics such as (gentamacin).

2. Further study should be investigated on the phytochemical constituent of the mushrooms $P$. citrinopileatus and $P$. tuber-regium.

\section{ACKNOWLEDGMENTS}

I wish to acknowledge and thank Mr. Chinedu Walamu for his time and patience in course of collecting these wild edible mushrooms in Oduoha-Emohua forest.

\section{REFERENCES}

Adejumo TO and Awosanya $\mathrm{OH}$ (2005). Proximate and mineral composition of four edible mushroom species from south western Nigeria. African Journal of Biotechnology, 4(10): 1084-1088.

Adejumo TO Coker ME and Akinmoladun VO (2015). Identification and evaluation of nutritional status of some edible and medicinal mushrooms in Akoko Area Ondo State, Nigeria. International Journal of Current Microbiology and Applied Sciences, 4 (4): 1011-1025.

Akindahunsi AA and Oyetayo FL (2006). Nutrient and anti-nutrient distribution of edible mushroom Pleurotus tuberregium (Fries) Singer. Lebensmillerlwissenschaft technology, 39(950):548-553.

Aletor VA and Aladetimi OO (1995). Compositional studies on edible tropical species of mushrooms. Food Chemistry, 54:65-268.
Aletor VA (1995). Compositional studies on edible tropical species of mushrooms, Food Chemistry 54:265-268.

Alofe FV Odeyemi AO and Oke OL (1996). Three wild mushrooms from Nigeria Journal of Microbiology, 1:29-34.

AOAC (2012). Association of analytical chemist official method of analysis $19^{\text {th }}$ ed. Gailhersbury, M. D. USA.

Arora D (1986). Mushrooms demystified. Ten Speed Press. p. 23. ISBN 0-89815-169-4.

Arora D (1986) Mushrooms Demystified, 2nd ed. Ten Speed Press.

Barbee G Berry-Cabán C Barry J Borys D Ward J and Salyer S (2009). "Analysis of mushroom exposures in Texas requiring hospitalization, 2005-2006". Journal of Medical Toxicology. 5 (2): 59-62.

Boa E (2004). Wild Edible Fungi: A Global Overview of their Use and Importance to People. Food and Agriculture Organization of the United Nations.

Borchers AT Krishnamurthy A Keen CL Meyers FJ and Gershwin ME (2008). "The Immunobiology of Mushrooms". Experimental Biology and Medicine. 233 (3): 259-76.

Bowerman S (2008). "If mushrooms see the light". Los Angeles Times.

Chang ST and Miles PG (1989). Edible mushrooms and their cultivation florida, CRS Press, Inc. 2738.

Chang, Shu-Ting \& Phillip G. M. (1989). Mushrooms: cultivation, nutritional value, medicinal effect, and Environmental Impact. CRC Press, 4-6.

Chukunda AF Zibokere DS Ukoima HN and Nwiisuator D (2008). Effects of Depth of planting hole on the performance of yam (Dioscorea rotundata Poir). Journal of Nigeria Environmental society; 4 (2); 2127.

Crisan EV and Sands A (1978). Nutritional Value of Edible Mushrooms. In: The Biology and Cultivation of Edible Mushrooms. Chang. ST. and W.A. Haves (Eds.). Academic press. New York. 137-168.

Elliott CE (1991). Reproduction in Fungi. First Edition.

Fasidi IO and Kadiri M (1990). Changes in nutritional content of two Nigerian mushrooms (. . robustus, and L.subnudus) during sporophore development. Die Nahrung. 31: 415-420.

Fasidi IO and Olorunmaiye KS (1994). Studies on the requirements for vegetative growth of Pleurotus tuberregium (Fr.) Singer. A Nigerian mushroom. Food Chem. 50: 397.

Food and Agriculture Organization of the United States

Hobbs CJ (1995). Medicinal Mushrooms: An Exploration of Tradition, Healing \& Culture. Portland, Oregon: Culinary Arts Ltd. 20.

John F (2010). "U.S. Mushroom Industry". Usda.mannlib.cornell.edu. Retrieved 2010-05-30.

Jonathan SG and Fasidi JO (2003). Antimicrobial activities of two Nigerian edible macrofungi- 
Lycoperdon pusilum and Lycoperdongiganteus. African Journal of Biomedical Research, 6: 84- 90.

Jordan P (2006). Field Guide to Edible Mushrooms of Britain and Europe. New Holland Publishers. p. 10.

Kadiri M. and Fasidi IO (1990). Variation in chemical composition of Chysophyllum molybditis (Mayerex Fr) Masses and Pleurotus tuber-regium (fries) during fruitbody development. Nigerian Journal Science, 24: 86-89.

Kalač, P and Svoboda L ( 2000). "A review of trace element concentrations in edible mushrooms". Food Chemistry. 69 (3): 273-281.

Kalaras MD Beelman RB Holick MF and Elias RJ (2012). "Generation of potentially bioactive ergosterolderived products following pulsed ultraviolet light exposure of mushrooms (Agaricus bisporus)." Food Chem. 135 (2): 396-401.

Koyyalamudi SR Jeong SC Song $\mathrm{CH}$ Cho KY and Pang G (2009). "Vitamin D2 formation and bioavailability from Agaricus bisporus button mushrooms treated with ultraviolet irradiation". J Agric Food Chem. 57 (8):

Lee GS Byun HS Yoon KH Lee JS Choi KC and Jeung EB (2009). "Dietary calcium and vitamin D2 supplementation with enhanced Lentinula edodes improves osteoporosis-like symptoms and induces duodenal and renal active calcium transport gene expression in mice". Eur J Nutr. 48 (2): 75-83.

Lentinan S (207). Memorial Sloan Kettering Cancer Center, New York.

Manzi PL Gambelli Marconi S Vivanti V and Pizzoferrato L (1999). Nutrients in edible mushrooms: An interspecies comparative study. Food Chemistry, 65: 477-482.

Marlow F (2001). Food Ltd, Quorn. http: www.quorn.conl.uk.index.htm.

Mattila P Suonpää K and Piironen V (2000). "Functional properties of edible mushrooms". Nutrition. 16 (7-8): 694-6.

Miles PG and Chang ST (1997). Mushroom biology: concise basics and current developments. Singapore: World Scientific.

$\mathrm{Ng}$ TB (1998). "A review of research on the proteinbound polysaccharide (polysaccharopeptide, PSP) from the mushroom Coriolus versicolor (basidiomycetes: Polyporaceae)". General Pharmacology: the Vascular System. 30 (1): 1-4.

Obodai M (1992). Comparative studies on the utilization of agriculture waste by some mushrooms (Pleurotus and Volvariella species). M. Phil. The University of Ghana, Legon.

Odebode SO (2005). Contributions of selected nontimber forest products to household food security in
Nigeria. Journal of Food and Agricultural Environment, 3: 138-141.

Oei P (2003). Mushroom cultivation, appropriate technology for mushroom growers. Backhughs Publishers, Leiden, Netherland.110 - 150.

Ola FL and Obah G (2001). Nutrient distribution and zinc bioavailability. Estimation in some tropical edible mushrooms. Nahrung 45: 67-68.

Osborne T (2016). "Deadly death cap mushrooms found in Canberra's inner-south as season begins early".

Osemwegie OO Okhuoya JA Oghenekaro $A O$ and Evueh GA (2010. Maerofungi community in rubber plantation and a forest of Edo State, Nigeria. Journal of Applied Science, 10 (5): 391-398.

Parent $O$ and Thoen D (1977). Food value of edible mushrooms from upper, Sheba region. Economic Botany, 31: 436-445.

Rubel W and Arora D (2008). "A study of cultural bias in field guide determinations of mushroom edibility using the iconic mushroom, Amanita muscaria, as an example" (PDF). Economic Botany. 62 (3): 22343.

Samme R Dell B Lumyong P Izumori K and Lumyong S (2003). Nutritive value of popular wild edible mushrooms from Northern Thailand. Food Chemistry, 83: 527532.

Steel RGD and Torrie JH (1980). Principles and Procedures of statistics: A biometrical approach. $2^{\text {nd }}$ edition. 597. McGraw Hill Book Company, New York.

Sullivan R Smith JE and Rowan NJ (2006). "Medicinal mushrooms and cancer therapy: translating a traditional practice into Western medicine". Perspectives in Biology and Medicine. 49 (2): 15970.

Sullivan R Smith JE and Rowan NJ (2006). "Medicinal Mushrooms and Cancer Therapy: translating a traditional practice into Western medicine". Perspectives in Biology and Medicine. 49 (2): 15970.

Ukoima HN Ogbonnaya LO Arikpo GE and Pepple GA (2009a). Nutritional, Organoleptic and Palatability Studies of Selected mushrooms in Nigeria. World Applied Science Journal of Pakistan, 7(4): 479-484.

Wasser PS (2007). A book review, mycelium running: how mushrooms can help save the world. Herbalgram 76: 50-57.

Wasser SP and Weis AL (1999). General description of the most important medicinal higher Basidiomycetes mushroom. International Medical Mushroom, 1:351370.

Zorhari MH (1973). Some edible mushrooms from Nigeria. Nigerian field, 38:81-90. 